\title{
Video Pembelajaran Bernuansa Problem Based Learning dengan Muatan IPS Kelas IV Sekolah Dasar
}

\author{
Ida Bagus Kade Raka Adnyana ${ }^{1^{*}}$ (i) \\ ${ }^{1}$ Program Studi Pendidikan Guru Sekolah Dasar, Universitas Pendidikan Ganesha, Indonesia \\ *Corresponding author: rakaadnyana1234@gmail.com
}

\section{Abstrak}

Penelitian ini dilatarbelakangi oleh permasalahan yang ada di lapangan mengenai kesulitan guru dalam menemukan media pembelajaran yang bisa digunakan pada pembelajaran daring. Tujuan penelitian ini menghasilkan video pembelajaran bernuansa Problem Based Learning muatan IPS kelas IV sekolah dasar. Penelitian ini merupakan penelitian pengembangan dengan model ADDIE (Analizye, Design, Development, Implementation, Evaluation). Metode pengumpulan data yang digunakan pada penelitian ini adalah metode wawancara, pencatatan dokumen dan kuesioner. Pada penelitian ini, uji rancangan video pembelajaran dilakukan oleh beberapa ahli dan siswa yang meliputi (1) ahli materi pembelajaran, (2) ahli desain pembelajaran, (3) ahli media pembelajaran, hingga (4) uji coba perorangan. Analisis yang digunakan adalah analisis data deskriptif kuantitatif dan kualitatif. Hasil penelitian menunjukkan bahwa validitas oleh para ahli, tingkat persentase kelayakan video pembelajaran berdasarkan ahli materi adalah sebesar 93,75\% dengan kualifikasi sangat baik. Tingkat persentase kelayakan menurut ahli desain pembelajaran adalah sebesar 90,38\%. Tingkat persentase kelayakan menurut ahli media 90,62\%. Tingkat persentase kelayakan video pembelajaran menurut uji coba perorangan sebesar $92,42 \%$ dengan kualifikasi sangat baik. Berdasarkan hasil penelitian dapat disimpulkan bahwa video pembelajaran bernuansa Problem Based Learning layak digunakan dalam proses pembelajaran pada muatan IPS kelas IV sekolah dasar.

Kata kunci: Video Pembelajaran, PBL, IPS

\section{Abstract}

This research is motivated by the problems that exist in the field regarding the difficulties of teachers in finding learning media that can be used in online learning. The purpose of this study was to produce a learning video with the nuances of Problem Based Learning for social studies content for grade IV elementary schools. This research is development research with the ADDIE model (Analyze, Design, Development, Implementation, Evaluation). Data collection methods used in this study were interviews, document recording, and questionnaires. In this study, the learning video design test was carried out by several experts and students which included (1) learning material experts, (2) learning design experts, (3) learning media experts, too (4) individual trials. The analysis used is descriptive quantitative and qualitative data analysis. The results showed that the validity by experts, the percentage level of feasibility of learning videos based on material experts was $93.75 \%$ with very good qualifications. The percentage level of feasibility according to learning design experts is $90.38 \%$. The percentage rate of eligibility according to media experts is $90.62 \%$. The percentage level of eligibility for learning videos according to individual trials is $92.42 \%$ with very good qualifications. Based on the results of the study, it can be concluded that the learning video with the nuances of Problem Based Learning is feasible to be used in the learning process on the content of social studies class IV elementary school.

\section{INTRODUCTION}

Menciptakan siswa yang memiliki pribadi dan keterampilan yang baik menjadi tugas yang sulit bagi setiap instansi pendidikan. Menyiapkan siswa yang memiliki keterampilan baik diperlukan tenaga pendidik atau guru yang baik pula. salah satu faktor yang mempengaruhi hasil belajar siswa adalah bagaimana guru dalam melaksanakan kegiatan pembelajaran (Immah et al., 2020; Syaidah et al., 2018). Sebagai profesi yang bertujuan untuk mencerdaskan kehidupan bangsa guru dituntut memiliki kualitas yang baik, karena kualitas guru dalam hal ini akan mempengaruhi prestasi siswa. Pada proses belajar mengajar, guru selalu dituntut untuk memberikan inovasi baru agar siswa mampu mendapatkan pengalaman baru dalam proses belajar mengajar. Inovasi ini diperlukan agar proses

\begin{tabular}{|c|c|c|}
\hline History: & & Publisher: Undiksha Press \\
\hline Received & : February 15, 2021 & Licensed: This work is licensed under \\
\hline Revised & : March 15, 2021 & a Creative Commons Attribution 3.0 License \\
\hline Accepted & : April 18, 2021 & (c) (†) () \\
\hline Published & : May 25, 2021 & (C) $\mathrm{BY}_{\mathrm{SA}}$ \\
\hline
\end{tabular}


pembelajaran menjadi menyenangkan dan menarik pada saat pandemi Covid-19. Inovasi pembelajaran dapat berupa pengembangan media pembelajaran dan metode pembelajaran.

Penggunaan media pembelajaran dapat menjadi salah satu terobasan sebagai inovasi pembelajaran (Wisada et al., 2019). Media pembelajaran ini contohnya power point, video pembelajaran, multimedia interaktif, dan lain-lain. Berdasarkan hasil observasi dan wawancara pada tanggal 10 Agustus 2020 ditemukan bahwa media pembelajaran di SD No. 2 Sedang masih belum memadai untuk kegiatan pembelajaran daring. Terlebih pada situasi COVID-19 pembelajaran dibatasi dengan aplikasi Whatsapp Group saja. Hal tersebut mengakibatkan siswa tidak semangat belajar sehingga pembelajaraan yang didapatkan siswa pun terbatas. Kurangnya semangat siswa untuk belajar diakibatkan karena rendahnya motivasi siswa. Motivasi belajar dapat berpengaruh pada prestasi belajar siswa dan berkaitan dengan pemenuhan rasa ingin tahu siswa (Hakim \& Mulyapradana, 2020; Marisa, 2019). Dengan siswa merasa kebutuhan belajar terpenuhi seperti ketersediaan media pembelajaran yang mendukung dan model pembelajaran yang menarik maka akan mampu meningkatkan rasa ingin tahu siswa. Selain itu pada situasi pembelajaran daring motivasi belajar siswa juga akan semakin meningkat apabila pilhan guru terhadap media pembelajaran dalam jaringan sesuai dan tepat untuk siswa.

Permasalahan tersebut jika dibiarkan maka akan berpengaruh terhadap hasil dan proses pembelajaran di sekolah tersbeut. Maka, diperlukan solusi untuk permasalahn tersebut. Salah satu solusi yang dapat dilakukan adalah dengan mengembangkan media pembelajaran berbasis model pembelajaran yang menarik di masa pembelajaran daring. Media video pembelajaran adalah sebuah media dengan penggunakan teknologi penangkapan, perekaman, dan penyimpanan gambar menyajikan adegan-adegan dalam gerak yang objeknya cenderung bersifat nyata dengan disertai suara (Pramana \& Suarjana, 2018; Risky, 2019; Thorifah \& Umam, 2019). Pemilihan video pembelajaran ini didasari penelitian yang pernah dilakukan sebelumnya yang menemukan bahwa penggunaan video pembelajaran memberikan pengaruh yang positif terhadap hasil belajar siswa sekolah dasar (Ariani et al., 2020; Novita et al., 2019). Sebagai inovasi dalam video pembelajaran yang dikembangkan, maka perlu didasari dengan model pembelajaran yang mampu melibatkan siswa dalam proses memecahkan masalah sosial. Model pembelajaran yang digunakan ialah problem based learning.

Model pembelajaran Problem Based Learning merupakan salah satu model pembelajaran yang melibatkan siswa untuk aktif belajar sesuai kurikulum 2013. Problem Based Learning merupakan pembelajaran yang menempatkan siswa terhadap suatu permasalahan nyata yang harus dipecahkan sehingga mendapatkan pengetahuannya sendiri (Pertiwi, 2018; Suardana, 2019). Dalam problem based learning masalah merupkan titik tolak suatu pembahasan untuk dianalisis dan ditemukan solusi atau jawabannya. Selain itu problem based learning juga merupakan cara dalam menggali informasi yang menampilkan problematika nyata sehingga akan memunculkan niat peserta didik untuk menyelidiki. Sebagai suatu pembelajaran yang bernuansa masalah dalam kehidupan sehari-hari akan mampu menumbuhkan minat siswa dalam memaknai masalah yang diaktualisasikan dalam video pembelajaran (Dewi, 2020; Meilasari et al., 2020).

Beberapa penelitian yang relevan dengan penelitian ini seperti yang dilakukan oleh (Wahyudi \& Agung, 2021) yang menemukan bahwa video pembelajaran berbasis Tri Hita Karana dinilai sangat valid dan layak digunakan pada muatan IPS kelas V SD. Kemudian penelitian lain juga menemukan bahwa video pembelajaran yang dikembangkan terbukti efektif meningkatkan motivasi dan hasil belajar kognitif siswa kelas IV SD Gugus Pacarejo (Suryansah \& Suwarjo, 2016). Penelitian lain juga menemukan bahwa video pembelajaran menggunakan model problem solving berbantu wondershare valid (layak menurut ahli) dan pembelajaran dengan video pembelajaran menggunakan model problem solving berbantu wondershare lebih efektif dari pada pembelajaran konvensional (Suriyani, 2017). Tujuan 
penelitian ini untuk menghasilkan video pembelajaran bernuansa Problem Based Learning muatan IPS kelas IV Sekolah Dasar.

\section{MATERIALS AND METHODS}

Jenis penelitan ini adalah penelitian pengembangan (Research and Development). Model penelitian pengembangan yang digunakan adalah model ADDIE (Analysis, Design, Development, Implementation, Evaluations) (Tegeh \& Kirna, 2010). Skema tahap model pengembangan dapat dilihat pada Gambar 1. Metode pengumpulan data dalam penelitian ini, yaitu dengan kuesioner. Instrument yang digunakan dalam penelitian ini berupa lembar validasi dari ahli materi, ahli desain dan ahli media, serta lembar uji coba perorangan dan kelompok kecil. Instrumen dalam penelitian pengembangan ini menggunakan skala bertingkat atau rating scale sesuai dengan kisi-kisi instrumen yang telah dibuat berdasarkan kajian pustaka terhadap produk yang dikembangkan, dan selanjutnya dikonsultasikan dengan dosen pembimbing penelitian. Kisi-kisi instrumen untuk kuesioner yang diberikan kepada ahli isi mata pelajaran dapat dilihat pada Tabel 1, kisi-kisi ahli desain pelajaran dapat dilihat pada Tabel 2, kisi-kisi untuk penilaian ahli media pelajaran dapat dilihat pada Tabel 3.

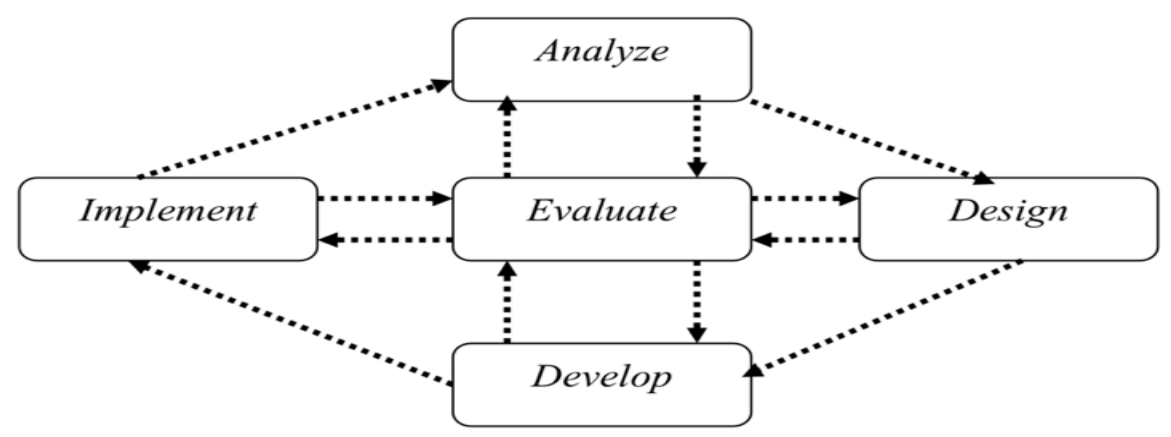

Gambar 1. SkemaTahap Model Pengembangan ADDIE

Sumber (Tegeh \& Kirna, 2010)

Tabel 1. Kisi-Kisi Instumen Ahli Mata Pelajaran

\begin{tabular}{|c|c|c|c|c|}
\hline No & Aspek & Indikator & Nomor Butir & Jumlah Butir \\
\hline \multirow{3}{*}{1} & \multirow{3}{*}{ Kurikulum } & $\begin{array}{l}\text { 1) Kesesuaian materi dengan } \\
\text { kompetensi dasar }\end{array}$ & 1 & \multirow{3}{*}{3} \\
\hline & & $\begin{array}{l}\text { 2) Kesesuaian materi dengan } \\
\text { indikator pembelajaran }\end{array}$ & 2 & \\
\hline & & $\begin{array}{l}\text { 3) Kesesuaian materi dengan } \\
\text { tujuan pembelajaran }\end{array}$ & 3 & \\
\hline \multirow{7}{*}{2} & \multirow{7}{*}{ Materi } & 4) Kebenaran materi & 4 & \multirow{7}{*}{7} \\
\hline & & 5) Keruntutan materi & 5 & \\
\hline & & 6) Kecakupan materi & 6 & \\
\hline & & 7) Pentingnya materi & 7 & \\
\hline & & $\begin{array}{l}\text { 8) Materi didukung dengan media } \\
\text { yang tepat }\end{array}$ & 8 & \\
\hline & & $\begin{array}{l}\text { 9) Konsep yang disajikan dapat } \\
\text { dilogikakan dengan jelas }\end{array}$ & 9 & \\
\hline & & 10)Tingkat kesulitan soal & 10 & \\
\hline 3 & Tata Bahasa & 11)Penggunaan bahasa yang tepat & 11 & 2 \\
\hline
\end{tabular}




\begin{tabular}{|c|c|c|c|c|}
\hline No & Aspek & Indikator & Nomor Butir & Jumlah Butir \\
\hline & & $\begin{array}{l}\text { dan konsisten } \\
\text { 12)Bahasa yang digunakan sesuai } \\
\text { dengan karakteristik siswa }\end{array}$ & 12 & \\
\hline & & Jumlah & & 12 \\
\hline
\end{tabular}

Tabel 2. Kisi-Kisi Ahli Desain Pembelajaran

\begin{tabular}{|c|c|c|c|c|}
\hline No & Aspek & $\begin{array}{c}\text { Indikator } \\
\end{array}$ & Nomor Butir & Jumlah Butir \\
\hline \multirow{4}{*}{1} & \multirow{4}{*}{ Ketepatan } & $\begin{array}{l}\text { 1) Kesesuaian video dengan } \\
\text { karakteristik siswa }\end{array}$ & 1 & \multirow[t]{4}{*}{ 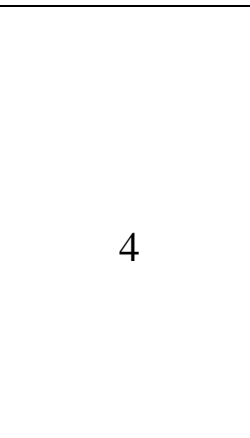 } \\
\hline & & $\begin{array}{l}\text { 2) Kesesuaian materi dengan } \\
\text { tujuan pembelajaran }\end{array}$ & 2 & \\
\hline & & $\begin{array}{l}\text { 3) Materi dalam video } \\
\text { pembelajaran dikemas secara } \\
\text { runtut }\end{array}$ & 3 & \\
\hline & & $\begin{array}{l}\text { 4) Tujuan pembelajaran sesuai } \\
\text { dengan format ABCD }\end{array}$ & 4 & \\
\hline \multirow{3}{*}{2} & \multirow{3}{*}{ Kejelasan } & $\begin{array}{l}\text { 5) Bahasa yang digunakan } \\
\text { mudah dipahami }\end{array}$ & 3 & \multirow{3}{*}{3} \\
\hline & & $\begin{array}{l}\text { 6) Kejelasan uraian dan } \\
\text { pembahasan }\end{array}$ & 4 & \\
\hline & & $\begin{array}{l}\text { 7) Kejelasan konten yang } \\
\text { disediakan }\end{array}$ & 5 & \\
\hline \multirow{2}{*}{3} & \multirow{2}{*}{ Minat } & $\begin{array}{l}\text { 8) Video memotivasi siswa } \\
\text { belajar }\end{array}$ & 8 & \multirow{2}{*}{2} \\
\hline & & $\begin{array}{l}\text { 9) Meningkatkan perhatian siswa } \\
\text { dalam proses pembelajaran }\end{array}$ & 9 & \\
\hline 4 & $\begin{array}{l}\text { Kualitas tes } \\
\text { dan } \\
\text { penilaiannya }\end{array}$ & $\begin{array}{l}\text { 10) Konsitensi evaluasi dengan } \\
\text { tujuan pembelajaran }\end{array}$ & 10 & 1 \\
\hline 5 & $\begin{array}{l}\text { Dampaknya } \\
\text { bagi siswa }\end{array}$ & $\begin{array}{l}\text { 11) Memudahkan pemahaman } \\
\text { siswa terhadap materi }\end{array}$ & 11 & 1 \\
\hline \multirow{2}{*}{6} & \multirow{2}{*}{ Desain Pesan } & $\begin{array}{l}\text { 12) Warna gambar nyaman } \\
\text { dipandang }\end{array}$ & 12 & \multirow{2}{*}{2} \\
\hline & & $\begin{array}{l}\text { 13) Ketepatan ilustrasi pada } \\
\text { deskripsi }\end{array}$ & 13 & \\
\hline
\end{tabular}

Tabel 3. Kisi-Kisi Ahli Media

Sumber: ( Supriatna dan Mochamad 2009)

\begin{tabular}{|c|c|c|c|c|}
\hline No & Aspek & Indikator & Nomor Butir & Jumlah Butir \\
\hline \multirow{6}{*}{1.} & \multirow{6}{*}{ Tampilan } & a. Keterbacaan teks & 1 & \multirow{6}{*}{14} \\
\hline & & b. Penggunaan gambar & & \\
\hline & & mendukung materi & 2 & \\
\hline & & pembelajaran & & \\
\hline & & $\begin{array}{l}\text { c. Penggunaan jenis huruf dan } \\
\text { ukuran huruf }\end{array}$ & 3 & \\
\hline & & $\begin{array}{l}\text { d. Penempatan gambar yang } \\
\text { tepat }\end{array}$ & 4 & \\
\hline
\end{tabular}




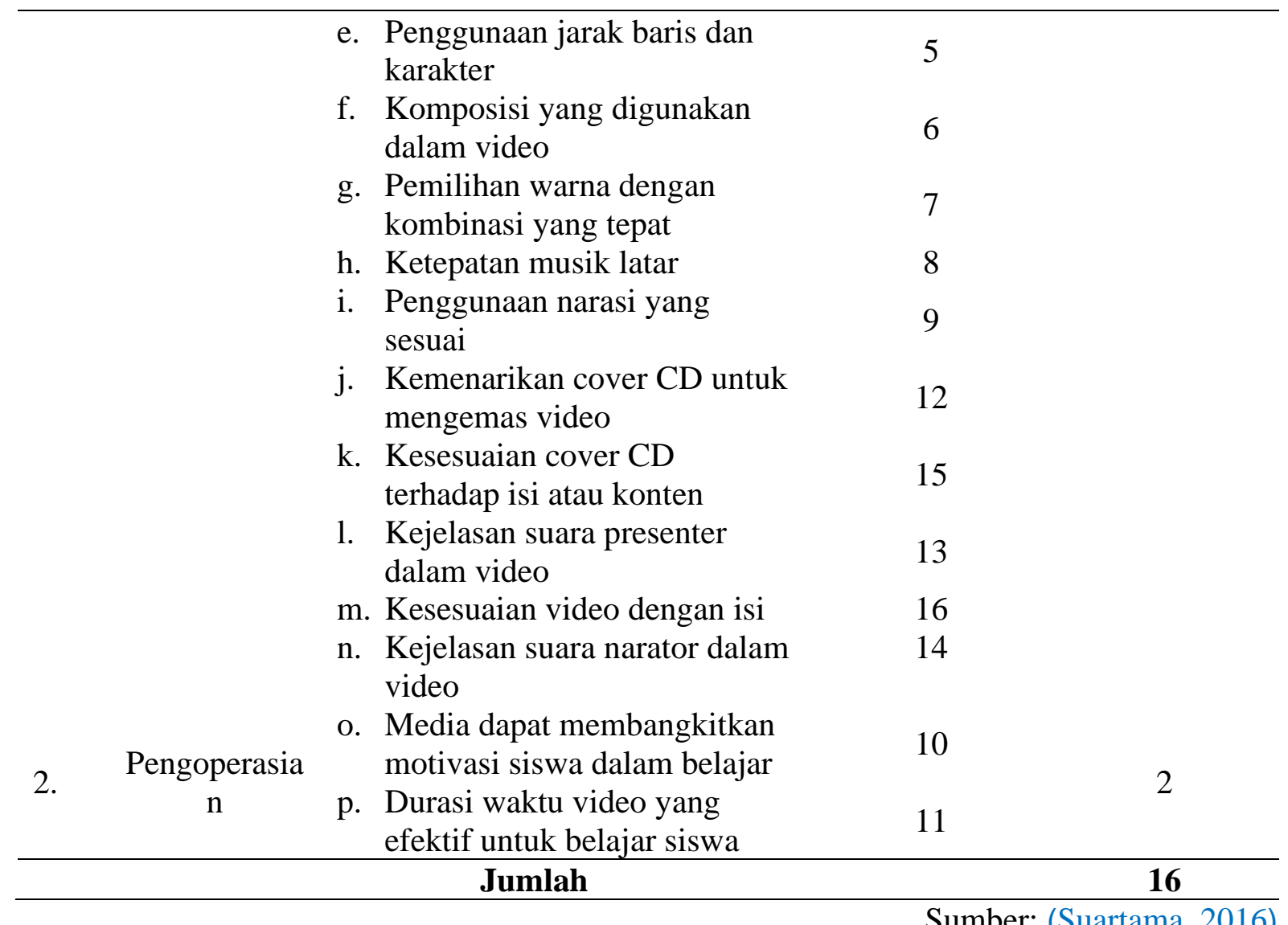

Jenis data dalam penelitian ini, yaitu data kualitatif dan kuantitatif. Dalam penelitian pengembangan ini metode dan teknik analisis data yang digunakan adalah analisis deskriptif kualitatif dan kuantitatif. Analisis deskriptif kualitatif digunakan untuk mengolah data yang bersumber dari komentar, tanggapan, kritik, dan saran berdasarkan uji para ahli, uji coba siswa secara perorangan dan uji coba kelompok kecil. Sedangkan analisis kuantitatif digunakan untuk mengetahui gambaran umum mengenai penyebaran data berupa skor yang sudah diperoleh dari lembar penilaian para ahli, uji coba perorangan dan uji coba kelompok. Untuk dapat memberikan makna dan pengambilan keputusan digunakan ketetapan digunakan tabel konversi tingkat pencapaian dengan skala 5 pada Tabel 4.

Tabel 4. Konversi Tingkat Pencapaian Skala 5

\begin{tabular}{cccc}
\hline Tingkat Pencapaian \% & Nilai Angka & Nilai Huruf & Predikat \\
\hline $90-100$ & 4 & A & Sangat Baik \\
$80-89$ & 3 & B & Baik \\
$65-78$ & 2 & C & Cukup \\
$40-64$ & 1 & D & Kurang \\
$00-39$ & 0 & E & Sangat Kurang \\
\hline & & \multicolumn{2}{c}{ Sumber: (Tegeh \& Kirna, 2010) }
\end{tabular}

Keterangan:

Sangat Baik = Sangat layak/ menarik

Baik $\quad=$ Layak/menarik

Cukup = Cukup layak/menarik

Kurang = Kurang layak/ menarik

Sangat Kurang = Sangat kurang layak/ menarik 


\section{RESULTS AND DISCUSSION}

Hasil penelitian ini terdiri dari dua pokok bahasan yaitu (1) deskripsi rancang bangun video pembelajaran (2) deskripsi validitas video pembelajaran. Adapun penjelasannya sebagai berikut. Rancang bangun video pembelajaran menggunakan model pengembangan ADDIE yang menggunakan 5 tahapan pengembangan. Adapun 5 tahapan model ADDIE berdasarkan pengembangan video pembelajaran sebagai berikut.

Tahap pertama yaitu tahap analisis. Tahap analisis dilakukan untuk memperoleh informasi berdasarkan kebutuhan siswa di lapangan. Tahap analisis meliputi analisis karakteristik siswa, analisis konten, analisis lingkungan atau fasilitas yang ada di sekolah. Pada analisis karakteristik siswa ditemukan bahwa siswa kelas IV SD No.2 Sedang lebih menyukai media video pembelajaran dalam proses pembelajaran. Berdasarkan analisis konten yang dilakukan dengan metode wawancara dengan wali kelas IV SD No.2 Sedang ditemukan bahwa materi pelajaran yang dikembangkan pada muatan IPS dengan materi keragaman suku bangsa dan budaya.

Tahap kedua yaitu tahap perancangan. Pada tahap perancangan dilakukan perancangan pembuatan rencana pelaksanaan pembelajaran (RPP), membuat storyboard, membuat naskah video pembelajaran dan mendesain kompenen video pembelajaran. Dalam tahap perancangan juga menentukan aplikasi yang tepat untuk membuat video pembelajaran. Adapun aplikasi yang digunakan untuk merancang kompenen yang ada pada video pembelajaran adalah Power Point 2019 dan Canva. Desain kompenen video pembelajaran meliputi perancangan tulisan, gambar dan background.

Tahap ketiga yaitu tahap pengembangan. Setelah melalui tahap perancangan maka dilanjutkan dengan menyusun setiap kompenen yang ada pada video dengan menggunakan aplikasi VN Video Editor. Pada tahap ini juga dilakukan penambahan musik, penambahan suara narator, penambahan efek transisi dan penambahan animasi. Selain itu juga dilakukan pinising agar video pembelajaran siap digunakan dan diujicobakan

Tahap keempat implementasi. Tahap implementasi bertujuan untuk mengetahui tingkat kelayakan video pembelajaran berdasarkan uji ahli materi pelajaran, uji desain pembelajaran, uji media pembelajaran dan uji coba perorangan. Uiji materi pembelajaran dilakukan oleh seorang dosen yang menguasai materi IPS, uji desain pembelajaran dan uji media pembelajaran dilakukan oleh seorang dosen Undiksha pada program studi teknologi pendidikan.

Tahap kelima yaitu tahap evaluasi. Tahap evaluasi dilakukan untuk menyempurnakan video pembelajaran berdasarkan komentar dan saran para ahli dan siswa. Evaluasi yang digunakan dalam penelitian ini adalah evaluasi formatif, dimana dalam penilaian yang bertujuan untuk mencari umpan balik dari hasil uji coba sebagai proses perbaikan Evaluasi formatif dapat juga diartikan sebagai penilaian yang bertujuan untuk mencari umpan balik (feedback), selanjutnya hasil penilaian tersebut dapat digunakan untuk memperbaiki proses belajar mengajar yang sedang atau sudah dilaksanakan (Fitrianti, 2018). Hasil dari tahapan evaluasi hasil validitas video pembelajaran berdasarkan uji coba para ahli dan uji coba perorangan didapatkan persentase tingkat kualitas video pembelajaran dapat dilihat pada Tabel 5.

Tabel 5. Hasil Uji Validitas Produk

\begin{tabular}{cccc}
\hline No & Subjek Uji Coba & Hasil Validitas (\%) & Persentase Kualifikasi \\
\hline 1 & Uji Ahli Isi & $93,75 \%$ & Sangat Baik \\
2 & Uji Ahli Desain Pelajaran & $90,38 \%$ & Sangat Baik \\
3 & Uji Ahli Media Pelajaran & $90,62 \%$ & Sangat Baik \\
4 & Uji Coba Perorangan & $92,42 \%$ & Sangat Baik \\
\hline
\end{tabular}


Berdasarkan Tabel 5 persentase hasil dari validitas video pembelajaran menurut ahli isi adalah sebesar 93,75\% dengan kualifikasi sangat baik sehingga layak diteruskan tanpa revisi. Hasil validitas video pembelajaran menurut ahli desain pembelajaran sebesar 90,38\% dengan kualifikasi sangat baik dan layak untuk digunakan dalam pembelajaran nampa revisi. Hasil uji media pembelajaran memperoleh skor persentase sebesar 90,62\% dengan kualifikasi sangat baik sehingga layak untuk digunakan. Kemudian hasil uji coba perorangan menunjukan tingkat persentase sebesar $92,42 \%$ dengan kualifikasi sangat baik dan layak digunakaan.

Setelah melalui evaluasi formatif untuk penyempurnaan produk maka dapat dihasilkan video pembelajaran yang layak digunakaan dalam kegiatan pembelajaran. Adapun yang direvisi oleh ahli media yaitu pada cover $\mathrm{CD}$. Tampilan cover $\mathrm{CD}$ setelah direvisi dapat dilihat pada Gambar 2.

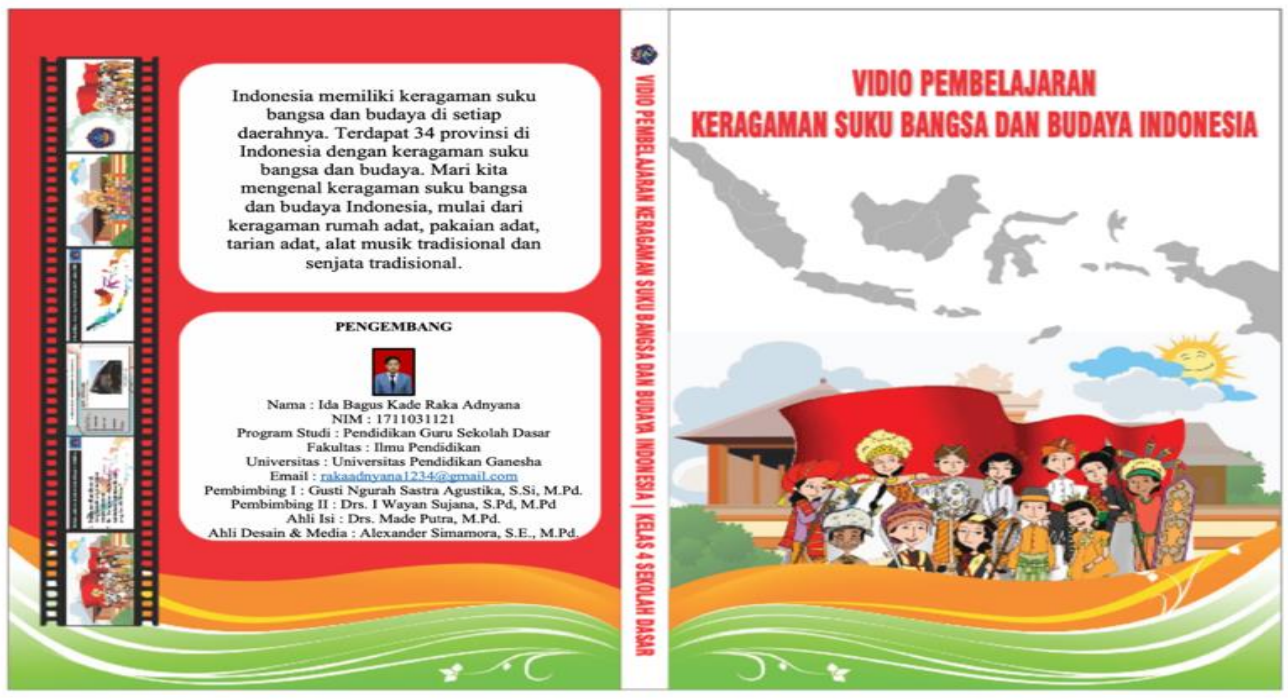

Gambar 2. Tampilan Cover CD setelah direvisi

Pada gambar 2, tampilan cover CD memuat beberapa komponen seperti judul, sinopsis video, gambar yang mendukung dan identitas pengembangan. Berdasarkan saran dan masukan dari ahli media pembelajaran tampilan cover CD yang sebelumnya menggunakan tampilan cara penggunaan diganti dengan menggunakan sinopsis. Penggunaan sinopsis ini dimasudkan untuk memudahkan siswa memahami isi apa saja yang terdapat pada video sehingga menambah daya Tarik siswa untuk menonton video.

Produk yang dihasilkan dalam penelitian ini berupa video pembelajaran bernuansa Problem Based Learning untuk kelas IV SD No 2 Sedang. Adapun model pengembangan yang dipilih adalah model ADDIE. Model ADDIE dipilih berdasarkan penelitian yang pernah dilakukan oleh (Liberta et al., 2020; Soesilo, 2020) bahwa model ADDIE memiliki kelebihan yaitu lebih serdehana, teratur serta sering digunakan dalam pembuatan media pembelajaran yang efektif dan tervalidasi oleh ahli. Selain itu model ADDIE juga pertimbangkan karena model ini disusun secara terprogram dan sistematis dalam rangka memecahkan masalah yang berkaitan dengan sumber belajar yang sesuai dengan karakteristik siswa. Model ADDIE memiliki 5 tahapan yang terdiri dari (Analysis, Design, Development, Implementation, Evaluations).

Pada tahap pertama yaitu analisis maka dilakukan beberapa analisis untuk mengetahui kebutuhan siswa. Berdasarkan penelitian yang dilakukan oleh (Dwi Lestari, 2020; Wijaya et al., 2020) pada tahap analisis yang dilakukan yakni menganalisis karakteristik siswa, 
kemampuan awal siswa, pemilihan materi pembelajaran yang sesuai serta lingkungan sekolah. Dengan melakukan analisis tersebut pengembangan video pembelajaran akan lebih efektif dan efisien. Setelah melalui tahap analisis maka dilanjutkan tahap desain, tahap desain yang digunakan dalam penelitian ini mempertimbangkam kriteria desain berdasarkan penelitian yang dilakukan oleh (Tegeh et al., 2019) yaitu tahap desain memuat tiga hal utama yang perlu dirancang seperti konsep media yang mempertimbangkan keserasian pemilihan warna pada media yang sesuai dengan karakteristik siswa. Selain itu pada konsep media juga mempertimbangkan penyimpanan hasil jadi video dalam bentuk CD. Pada konsep naskah memuat uraian lengkap setiap adegan dengan jenis musik, efek suara, sumber visual, dimana hasil dari naskah tersebut yang akan digunakan sebagai pedoman pembuatan video. Tahap selanjutnya adalah pengembangan. Pada tahap pengembangan ini setiap bagian dalam tahap desain akan dikembangkan. Guru harus mampu mengembangkan suatu media yang inovatif, kreatif dan efektif berdasarkan pada prinsip pengembangan media yakni sesuai dengan karakteristik siswa (Puryono, 2020). Setelah melalui tahap pengembangan barulah video pembelajaran dapat dinilai oleh para ahli dan siswa. Untuk memaksimalkan media yang dibuat maka dilakukan evaluasi secara formatif. Evaluasi formatif merupakan langkah pertama dalam memahami nilai pada penelitian pengembangan untuk mengetahui kelayakan media pembelajaran (Anggrawan, 2018).

Kelayakan video pembelajaran berdasarkan hasil penilaian dari ahli isi/ materi menunjukan persentase sebesar 93,75\% dengan kualifikasi sangat baik. Kelebihan video pembelajaran ini sehingga sangat baik karena kesesuaian materi pembelajaran dengan situasi di dunia nyata. Media pembelajaran khususnya untuk usia sekolah dasar sangat penting untuk membuat media yang sesuai dengan kenyataan di lingkungan siswa secara konkret (Atik, 2019). Selain itu kelebihan video pembelajaran ini juga terdapat pada kejelasan dan kebenaran isi materi pembelajaran. Pembuatan media isi materi pembelajaran yang jelas dan objektif mampu meningkatkan pemahaman siswa dengan baik karena bersifat konkret (Rizal, 2019).

Kelayakan video pembelajaran berdasarkan penilaian dari ahli desain menunjukan hasil sebesar 90,38\% dengan kualifikasi sangat baik. Kelbihan dari aspek desain yaitu pada kemenarikan video yang mampu membangkitkan motivasi siswa, dimana hal ini sesuai dengan penelitian yang pernah dilakukan oleh (Alfansyur, 2019; Widiasih et al., 2018) dimana motivasi dalam media pembelajaran akan mampu membangkitkan semangat siswa untuk belajar serta mampu meningkatkan prestasi belajar siswa. Untuk meningkatkan motivasi tersebut haruslah menggunakan media pembelajaran yang sesuai. Ini berarti video pembelajaran merupakan media pembelajaran yang sesuai untuk siswa sekolah dasar.

Pada penilaian ahli media pembelajaran memperoleh skor persentase sebesar 90,62\% dengan kualifikasi sangat baik. Kualifikasi sangat baik pada media pembelajaran dipengaruhi oleh beberapa hal yakni kemenarikan media, kejelasan pemilihan jenis, ukuran, warna dan teks yang digunakan dalam video pembelajaran. Kemenarikan video pembelajaran yang menyajikan gambar dan suara yang menarik sangat efektif memvisualisasikan materi pembelajaran sehingga siswa dapat memahami konten yang terdapat pada video pembelajaran (Ayu et al., 2020). Selain itu video pembelajaran bernuansa Problem Based Learning memiliki kelebihan dalam pemilihan backsound yang tepat dan suara narrator yang jelas. Siswa tidak menyukai pemilihan backsound yang kurang tepat dan volume suara yang kurang jelas karena dapat mempengaruhi kemampuan siswa untuk memahami apa yang tersaji pada video (Wulandari, 2020). Berdasarkan kelebihan tersebut maka video pembelajaran bernuansa Problem Based Learning dapat memudahkan siswa memahami materi pelajaran.

Setelah melalui tahap penilaian kelayakan media oleh para ahli maka dapat dilakukan uji coba kepada siswa. Berdasarkan uji coba perorangan persentase yang didapatkan sebesar 
92,42\% dengan kualifikasi sangat baik. Kualifikasi sangat baik didapatkan berdasarkan penilaian oleh siswa dimana video pembelajaran mudah dipahami oleh siswa serta tampilan video yang menarik. Video pembelajaran yang dikemas dengan menarik dan menyenangkan akan membuat proses belajar mengajar dapat berjalan dengan menyenangkan sehingga mampu meningkatkan semangat siswa (Arif, 2019; Dwijayanti, 2021). Selain itu penggunaan media juga harus didasari dengan tujuan untuk memudahkan siswa memahami materi pelajaran.

Hasil penelitian ini didukung oleh hasil penelitian yang dilakukan oleh (Wahyudi \& Agung, 2021) yang menemukan bahwa video pembelajaran berbasis Tri Hita Karana dinilai sangat valid dan layak digunakan pada muatan IPS kelas V SD. Kemudian penelitian lain juga menemukan bahwa video pembelajaran yang dikembangkan terbukti efektif meningkatkan motivasi dan hasil belajar kognitif siswa kelas IV SD Gugus Pacarejo (Suryansah \& Suwarjo, 2016). Penelitian lain juga menemukan bahwa video pembelajaran menggunakan model problem solving berbantu wondershare valid (layak menurut ahli) dan pembelajaran dengan video pembelajaran menggunakan model problem solving berbantu wondershare lebih efektif dari pada pembelajaran konvensional (Suriyani, 2017).

\section{CONCLUSION}

Video pembelajaran bernuansa Problem Based Learning memenuhi katagori layak berdasarkan penilaian dari ahli isi, ahli desain, ahli media serta siswa. Dari aspek isi atau materi video pembelajaran bernuansa Problem Based Learning memiliki keunggulan dimana materi pembelajaran sesuai dengan tujuan pembelajaran dan situasi di dunia nyata. Sementara pada aspek desain dan media, video pembelajaran memiliki keunggulan dalam kemenarikan tampilan video serta mampu meningkatkan motivasi siswa untuk belajar. Sehingga video pembelajaran Bernuansa Problem Based Learning dapat dikatan layak untuk digunakan dalam kegiatan pembelajaran untuk siswa kelas IV sekolah dasar.

\section{REFERENCES}

Alfansyur, A., \& Mariyani, M. (2019). Pemanfaatan Media Berbasis ICT "Kahoot" Dalam Pembelajaran PPKn untuk Meningkatkan Motivasi Belajar Siswa. Bhineka Tunggal Ika: Kajian Teori dan Praktik Pendidikan PKn, 6(2), 208-216. https://doi.org/10.36706/jbti.v6i2.10118.

Anggrawan, A., \& Satria, C. (2018). Tinjauan Kritis Jurnal Ilmiah: Pengembangan dan Evaluasi Formatif Studi Kasus Multimedia untuk Siswa Desain dan Teknologi Pembelajaran. Matrik: Jurnal Manajemen, Teknik Informatika dan Rekayasa Komputer, 18(1), 146-158. https://doi.org/10.30812/matrik.v18i1.328.

Ariani, K. R., Sumantri, M., \& Parmiti, D. P. (2020). Pengembangan Video Pembelajaran IPS Bermuatan Tes untuk Siswa. Jurnal Ilmiah Pendidikan Profesi Guru, 3(2), 217. https://doi.org/10.23887/jippg.v3i2.28260.

Arif, Muhammad Faisal; Praherdhiono, Henry; Adi, E. P. (2019). Pengembangan Video Pembelajaran IPA Materi Gaya untuk Siswa Sekolah Dasar. Jurnal Kajian Teknologi Pendidikan, 2(4), 329-335.

Atik, K. M. (2019). Pelatihan Pembuatan Dan Pemanfaatan Media Pembelajaran Pada Guru Di Ppt Nur Insani Surabaya. Journal Community Development and Society, 1(2), 8998. https://doi.org/10.25139/cds.v1i2.1810.

Ayu, I. G., Manik, A., \& Simamora, A. H. (2020). Pengembangan Pembelajaran Blended Pada Mata Kuliah Ahara Yoga Semester II di IHDN Denpasar. 8, 1-15.

Dewi, D. T. (2020). Penerapan Problem Based Learning untuk Meningkatkan Kemampuan 
Berpikir Kritis Siswa. Jurnal Pendidikan Ekonomi Undiksha, 12(1), 1. https://doi.org/10.23887/jjpe.v12i1.25317.

Dwi Lestari, H., \& Putu Parmiti, D. P. P. (2020). Pengembangan E-Modul Ipa Bermuatan Tes Online Untuk Meningkatkan Hasil Belajar. Journal of Education Technology, 4(1), 73. https://doi.org/10.23887/jet.v4i1.24095.

Dwijayanti, K. I. (2021). Pembuatan Media Video Pembelajaran Interaktif Teknik Pemijatan Pada Wajah di SMK Kiki. Syntax Idea, 3(1), 6.

Fitrianti, L. (2018). Prinsip Kontinuitas dalam Evaluasi Proses Pembelajaran. Jurnal Pendidikan, 10(1), 89-102.

Hakim, M., \& Mulyapradana, A. (2020). Pengaruh Penggunaan Media Daring dan Motivasi Belajar Terhadap Kepuasan Mahasiswa Pada Saat Pandemik Covid-19. Widya Cipta: Jurnal Sekretari dan Manajemen, 4(2), 154-160. https://doi.org/10.31294/widyacipta.v4i2.8853.

Immah, F., Sukidin, S., \& Kartini, T. (2020). Pengaruh Kompetensi Profesional Guru Terhadap Kinerja Guru di SMA Negeri 01 Kalisat Tahun Pelajaran 2018/2019. Jurnal Pendidikan Ekonomi: Jurnal Ilmiah Ilmu Pendidikan, Ilmu Ekonomi Dan Ilmu Sosial, 14(1), 253. https://doi.org/10.19184/jpe.v14i1.12493.

Liberta Loviana Carolin, I Ketut Budaya Astra, \& I Gede Suwiwa. (2020). Pengembangan Media Video Pembelajaran Dengan Model Addie Pada Materi Teknik Dasar Tendangan Pencak Silat Kelas Vii Smp Negeri 4 Sukasada Tahun Pelajaran 2019/2020. Jurnal Kejaora (Kesehatan Jasmani Dan Olah Raga), 5(2), 12-18. https://doi.org/10.36526/kejaora.v5i2.934.

Marisa, S. (2019). Pengaruh Motivasi dalam Pembelajaran Siswa Upaya Mengatasi Permaslahan Belajar. Jurnal Taushiah FAI-UISU, 9(2), 20-27.

Meilasari, S., M, D., \& Yelianti, U. (2020). Kajian Model Pembelajaran Problem Based Learning (PBL) dalam Pembelajaran di Sekolah. Jurnal Pendidikan Biologi Dan Sains, 3(2), 195-207.

Novita, L., Sukmanasa, E., \& Pratama, M. Y. (2019). Indonesian Journal of Primary Education Penggunaan Media Pembelajaran Video terhadap Hasil Belajar Siswa SD. 3(2), 64-72.

Pertiwi, S. (2018). Penerapan Model Problem Based Learning Berbantuan Media Interaktif untuk Meningkatkan Hasil Belajar Matematika. 1(1), 114-123.

Pramana, I. P. Y., \& Suarjana, I. M. (2018). Pengaruh Model Pembelajaran Time Token Berbantuan Media Video Terhadap Hasil Belajar IPA Kelas V SD. Journal of Education Technology, 4(2), 137-144. https://doi.org/http://dx.doi.org/10.23887/jet.v2i4.16425.

Puryono, D. A. (2020). Pelatihan Pembuatan Video Pembelajaran Untuk Guru Sd Kristen Terang Bagi Bangsa Pati Menggunakan Kinemaster. Jurnal Pengabdian Vokasi, 01(04), 242-247.

Risky, S. M. (2019). Analisis Penggunaan Media Video pada Mata Pelajaran IPA di Sekolah Dasar. Sekolah Dasar: Kajian Teori Dan Praktik Pendidikan, 28(2), 73-79. https://doi.org/10.17977/um009v28i22019p073.

Rizal, S., \& Walidain, B. (2019). Pembuatan Media Pembelajaran E-Learning Berbasis Moodle Pada Matakuliah Pengantar Aplikasi Komputer Universitas Serambi Mekkah. Jurnal Ilmiah Didaktika: Media Ilmiah Pendidikan Dan Pengajaran, 19(2), 178. https://doi.org/10.22373/jid.v19i2.5032.

Soesilo, A., \& Munthe, A. P. (2020). Pengembangan Buku Teks Matematika Kelas 8 Dengan Model ADDIE. Scholaria: Jurnal Pendidikan Dan Kebudayaan, 10(3), 231-243. https://doi.org/10.24246/j.js.2020.v10.i3.p231-243

Suardana, P. (2019). Penerapan Model Pembelajaran Problem Based Learning (PBL) dengan 
Metode Demonstrasi untuk Meningkatkan Hasil Belajar Permainan Tolak Peluru. Journal of Education Action Research, 3(3), 270. https://doi.org/10.23887/jear.v3i3.17974

Suriyani, I. (2017). Pengembangan Video Pembelajaran Menggunakan Model Problem Solving Berbantu Wondershare Pada Materi Statistika Di Smp. Aksioma, 7(1), 1. https://doi.org/10.26877/aks.v7i1.1405

Suryansah, T., \& Suwarjo, S. (2016). Pengembangan Video Pembelajaran Untuk Meningkatkan Motivasi Dan Hasil Belajar Kognitif Siswa Kelas IV SD. Jurnal Prima Edukasia, 4(2), 209. https://doi.org/10.21831/jpe.v4i2.8393

Syaidah, U., Suyadi, B., \& Ani, H. M. (2018). Pengaruh Kompetensi Guru Terhadap Hasil Belajar Ekonomi Di Sma Negeri Rambipuji Tahun Ajaran 2017/2018. Jurnal Pendidikan Ekonomi: Jurnal Ilmiah Ilmu Pendidikan, Ilmu Ekonomi Dan Ilmu Sosial, 12(2), 185. https://doi.org/10.19184/jpe.v12i2.8316

Tegeh, I. M., \& Kirna, I. M. (2010). Metode Penelitian Pengembangan Pendidikan. Universitas Pendidikan Ganesha.

Tegeh, I. M., Simamora, A. H., \& Dwipayana, K. (2019). Pengembangan Media Video Pembelajaran Dengan Model Pengembangan 4D Pada Mata Pelajaran Agama Hindu. Mimbar Ilmu, 24(2), 158. https://doi.org/10.23887/mi.v24i2.21262

Thorifah, S. B. A. A., \& Umam, K. (2019). The influence of use audio visual media to increase the development of early childhood language. Indria, 4(2), 146-155. http://dx.doi.org/10.24269/jin.v4n2.2019.pp146-155

Wahyudi, I. M. D., \& Agung, A. A. G. (2021). Pengembangan Video Pembelajaran Berbasis Tri Hita Karana Pada Muatan Pelajaran IPS Kelas V SD. Jurnal Pedaagogi Dan Pembelajaran, 4(1), 49-58. http://dx.doi.org/10.23887/jp2.v4i1.32105

Widiasih, R., Widodo, J., \& Kartini, T. (2018). Pengaruh Penggunaan Media Bervariasi Dan Motivasi Belajar Terhadap Hasil Belajar Mata Pelajaran Ekonomi Siswa Kelas Xi Ips Sma Negeri 2 Jember Tahun Pelajaran 2016/2017. Jurnal Pendidikan Ekonomi: Jurnal Ilmiah Ilmu Pendidikan, Ilmu Ekonomi Dan Ilmu Sosial, 11(2), 103. https://doi.org/10.19184/jpe.v11i2.6454

Wijaya, T. T., Purnama, A., \& Tanuwijaya, H. (2020). Pengembangan Media Pembelajaran Berdasarkan Konsep Tpack pada Materi Garis dan Sudut Menggunakan Hawgent Dynamic Mathematics Software. JPMI - Jurnal Pembelajaran Matematika Inovatif, 3(3), 205-214. https://doi.org/10.22460/jpmi.v1i3.205-214

Wisada, P. D., Sudarma, I. K., \& Yuda S, A. I. W. I. (2019). Pengembangan Media Video Pembelajaran Berorientasi Pendidikan Karakter. Journal of Education Technology, 3(3), 140. https://doi.org/10.23887/jet.v3i3.21735

Wulandari, E., \& Nugroho, W. (2020). Sikap Siswa terhadap Video Pembelajaran Jarak Jauh Materi Statistika pada Media Sosial Youtube. Edumatica: Jurnal Pendidikan Matematika, 10(2), 1-9. 